\title{
Schematic Design Process in Block Plan Building Industrial Block in Gianyar-Bali
}

\author{
Aswin Pandu Dinata ${ }^{1}$, Syamsul Alam Paturusi ${ }^{2}$, I Gusti Bagus Budjana ${ }^{3}$ \\ Bachelor Degree of Architecture Study Program \\ Faculty of Engineering-Udayana University \\ Jimbaran \\ pandudinata66@gmail.com \\ Architecture Study Program \\ Faculty of Engineering-Udayana University \\ Jimbaran \\ Architecture Study Program \\ Faculty of Engineering-Udayana University \\ Jimbaran
}

\begin{abstract}
Plastic waste is now a common thing happening in the community so that it becomes a major problem in environmental pollution. The growing population and changing lifestyle of society led to the ever increase volume of plastic waste are generated every day. Please note that the plastic waste is inorganic waste that can not be broken down by bacteria, even if dumped in any place, the plastic waste takes long times until the plastic waste is destroyed by itself because of the influence of air temperature or climate. It is not good if the processing of plastic waste is done by way of burnt be-cause it may cause air pollution which is harmful to living beings and the environment. Therefore, it would be nice if the plastic waste can be reuse through the processing of ore into plastic or made into new products in the form of a craft that is more usable and valuable. Processing of plastic waste that is done well can aid in the reduction of the number of plastic waste, so it is needed a design of Industrial plastic waste as the place of processing plastic waste. As for the de-sign of this facility beginning with the stages of the design process as the initial schematic in deciding the block plan of the building. Schematic design can be use as a reference in the design process because it includes design ideas.
\end{abstract}

Index Terms - industry, plastic waste, environment.

\section{INTRODUCTION}

At this time almost everyone will use plastic materials in their daily activities. Plastic material has become an important component in human life today because of its advantages, among others, lightweight, strong and resistant to corrosion. The properties of this plastic material make it difficult to replace even often used in everyday life starting from food packaging or household appliances. Gianyar Regency itself can be said as a district that produces plastic waste with an amount that is always increasing every year. Most of the rubbish is generated from household industry and trade activities. Based on data from the Department of the Environment (DLH) of Gianyar Regency, the projected plastic pile in Gianyar Regency in 2017 is $258.2 \mathrm{~m} 3$ / day. In general, the waste management system implemented in Gianyar Regency has started to apply the principle of waste reduction and handling. However, these efforts have not been able to significantly reduce the amount of plastic waste given the unavailability of plastic waste management facilities. Most of the organic and inorganic waste in Gianyar Regency is sent to the Temesi TPA. Here organic waste is processed to be used as a post, but for inorganic waste, especially plastic waste, it does not get treatment like organic waste. A small 
portion of the plastic waste sent to the Temesi landfill is made into handicrafts and most of it is sold back to plastic waste collectors. The lack of plastic waste management facilities in Gianyar Regency causes plastic garbage collectors or garbage banks to choose to sell or send their waste outside Gianyar Regency. Thus, there needs to be a facility that can manage plastic waste, especially in Gianyar Regency. The planning of the Plastic Waste Industry in Gianyar is expected to reduce the accumulation of plastic waste by processing plastic waste into plastic raw materials (plastic seeds) and crafts which can then be marketed. The design of this facility begins with the schematic design stage as a process in determining the building plan blocks which can then be used as a reference in the next design process.

\section{RESULt AND ANALISYS}

\section{A. Schmatic Design}

Schematic design is the initial stage in designing a building design that is developed through design ideas or ideas in the form of basic sketches, graphics, and design schemes which form the basis of the next design stage. The idea of the emergence of schematic design is guided by the existence of design criteria. The design criteria become a reference or a basic key in the design stage of schematic design. Applying the right design criteria to the schematic design will produce an optimal schematic design and in accordance with the objectives to be achieved.

\section{B. Matric Diagram}

Matrix diagrams are used to determine the relationship between each space and its function[1]. Spatial relations can be divided into two types of relationships, namely relationships between macro spaces and relationships between micro spaces. The relationship between macro spaces is the relationship between the main space groups, management space and supporting space, while the relationship between micro spaces is the relationship between spaces within each of these space groups. Matrix diagrams are obtained based on a predetermined community activity process, thus producing space requirements.

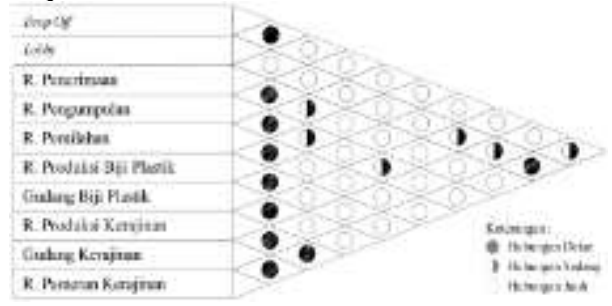

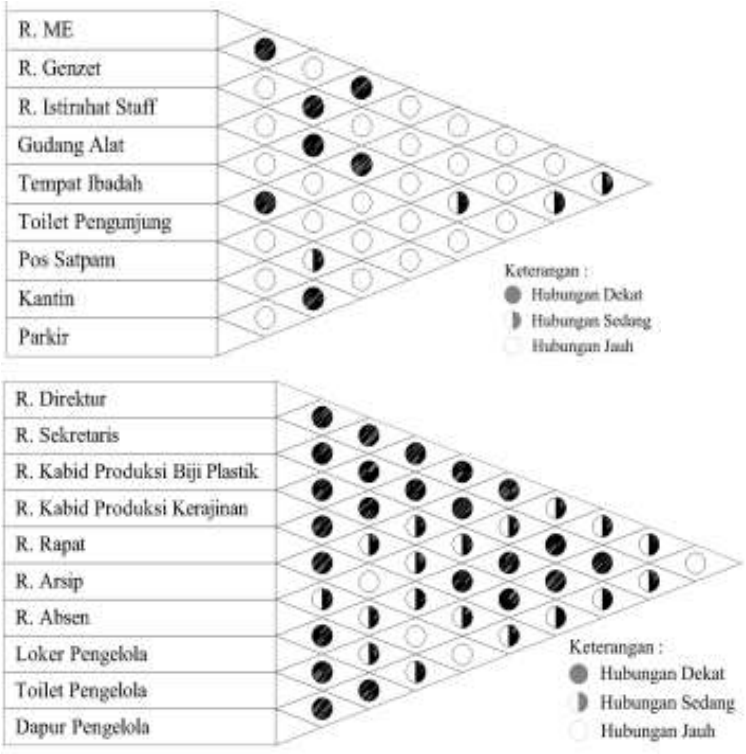

Fig. 1. Fish Diagram

Close Relationship is the relationship between spaces between these spaces experiences the most intense or frequent intensity of activities. In addition, for placement the space must also be close or side by side. Medium Relationship is a relationship between spaces that has an intensity of activity relationships that can be categorized quite often, but the placement of space can still not coexist. Distant Relationship is a relationship between spaces where the activities between the spaces do not have a connection and the placement between the spaces is quite far.

\section{Space Organization}

Space organization is the result of grouping of each room with the main function, manager and support. Spatial organization aims to obtain the placement of spaces that can support the smooth circulation and comfort of the perpetrators (civitas) in carrying out their activities in buildings. Space organization is made based on a predetermined matrix diagram. 


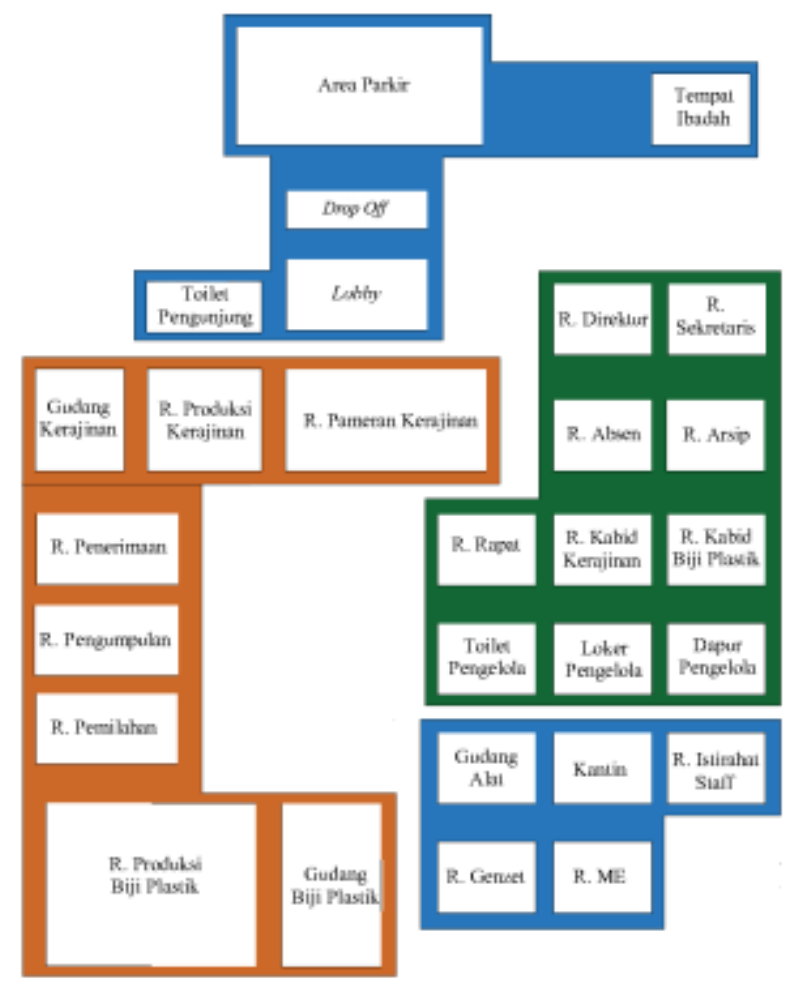

Fig. 2. Space Organization

Space circulation is a movement from space to space carried out with consideration of the activity actors, activity processes, types of space and spatial relations. The circulation in Figure 3. above is divided into circulation of exhibition visitors, visitors who carry plastic waste, nonproduction managers and production managers.

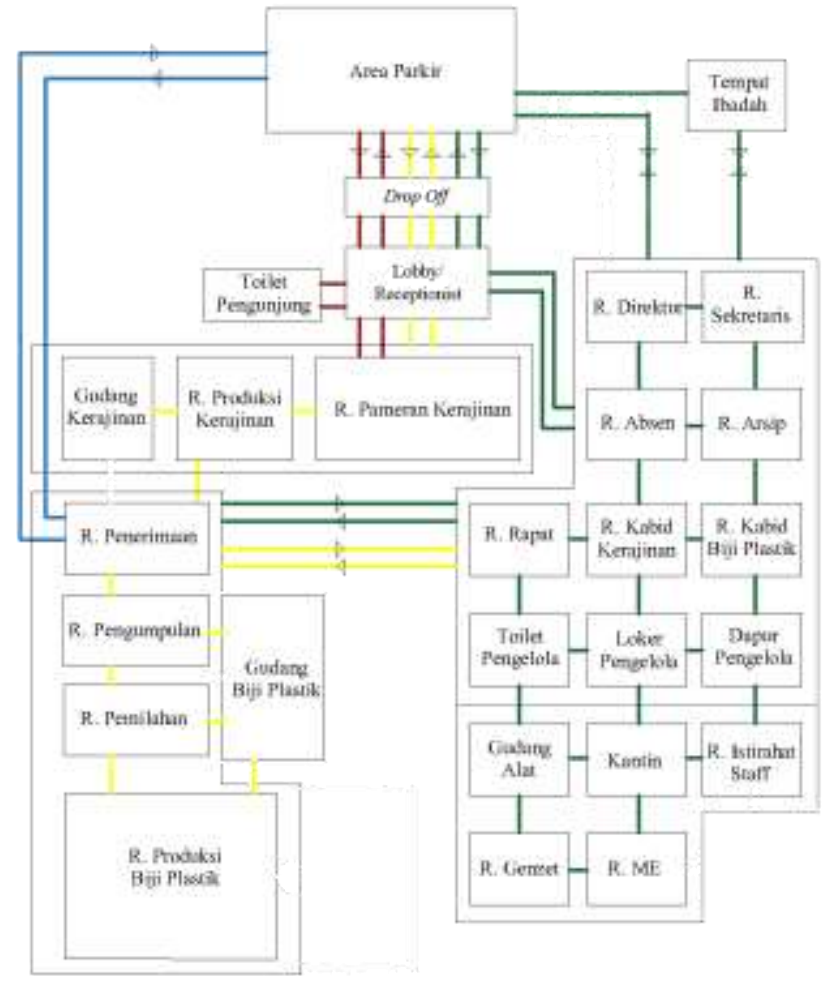

Fig. 3. Circulation

\section{Zoning}

Zoning in the design comes from the organization of space that has been determined based on civitas, activity patterns and the amount of space. Zoning aims to make it easier to determine the circulation of humans, goods, and vehicles in their sites related to their function as industrial buildings and handicraft production. The figure below shows how the zoning schematic analysis is obtained from several considerations.
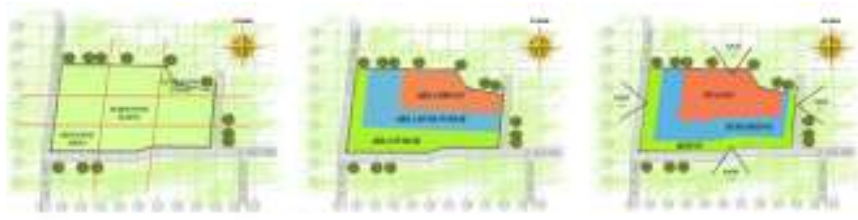

Fig. 4. Zoning

Based on the previous zoning analysis, the zoning schematic shown in Figure 7. is obtained. The zoning is divided into several buildings with unclear dimensions, but certain circulation and placement have been seen. Blue zoning is a building with the main function, while red zoning is a building with management and support functions. Buildings with manager functions are in the area with the lowest noise so as not to interfere with the manager's activities. Furthermore, this zoning scheme will become a reference in determining the shape and pattern of the building mass.

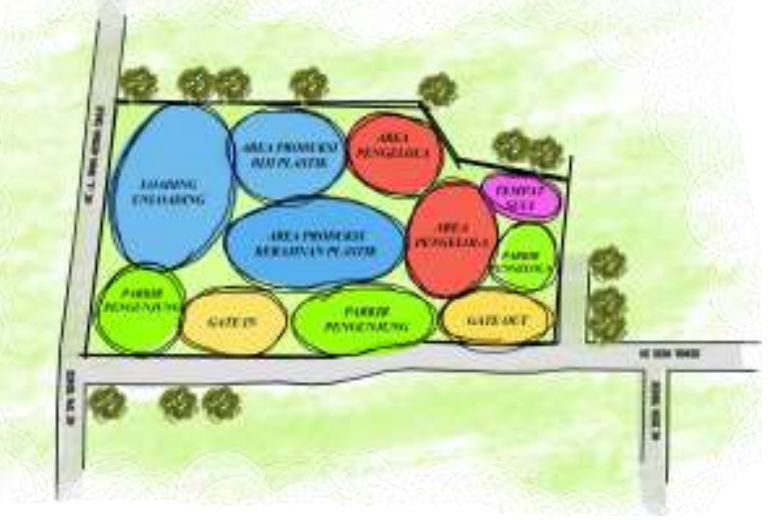

Fig. 4. Zoning

\section{E. Schematic Application of Mass Forms}

The schematic application of mass forms and patterns in buildings is shown in figure 8 . In addition to building placement based on cluster mass patterns. Related to the main function, which is the sale of plastic crafts and the production of plastic pellets, the placement of buildings in clusters will facilitate the circulation of civitas and goods. The shape of the mass of a square and rectangular building was chosen because it can optimize the function of space. 


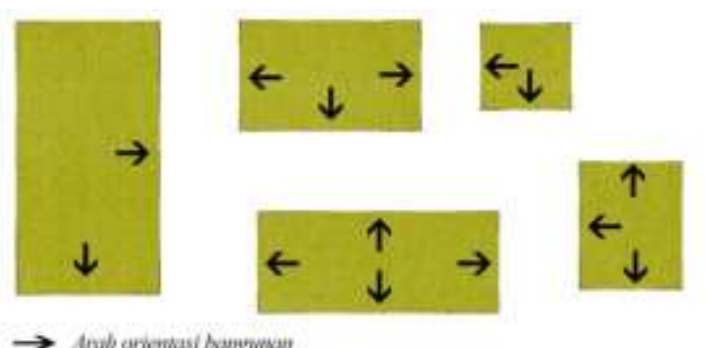

Fig. 5. Shape and Pattern of Building Mass

\section{F. Schematic Application of Mass Forms}

In Figure 6. Besides, number one is the part for loading dock oriented southward close to the en-trance and far from other buildings so as not to interfere with other visitors' activities and the building can be seen from the west. Number two is the production area which has a rectangular shape to optimize space. Number three is the lobby and the plastic trash / artshop craft area into a unified period to streamline visitor circulation. Number four is the area of management oriented west and south to get a western and southern view. Number five is intended for the ME room to be close to the production area and close to the management area to facilitate maintenance.

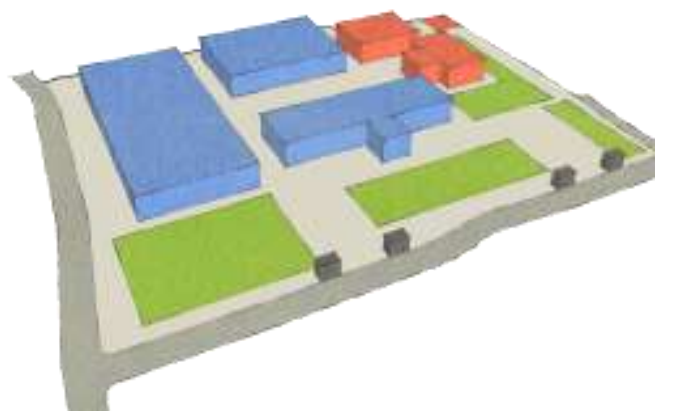

Fig. 6. Shape and Pattern of Building Mass

\section{CONCLUSION}

The process of designing a block plan in the Plastic Waste Industry building in Gianyar applies a design schematic that is the basis or initial design of the design with reference to design criteria. In the application of this schematic design there is a process of matrix diagrams, spatial organization, space circulation, zoning as well as the shape and pattern of building mass. Application of design schematics in building block plans that can be used as guidelines in designing layouts making it easier in the next design process.

\section{REFERENCES}

[1] Panero, Julius dan Zelnik, Matrin, "Dimensi Manusia dan Ruang Interior: Buku Panduan untuk Standar Pedoman Perancangan", United State: Whitney Library of Design, 1979. 